ISSN: 1576-0162

\title{
Cohesion Performance and Sustainable Development PROGRESS IN EU StATES
}

\author{
DESEMPEÑO DE LA COHESIÓN Y PROGRESO DE DESARROLLO \\ SOSTENIBLE EN LOS ESTADOS DE LA UE
}

Roxana Maria Bădîrcea

University of Craiova roxanamariapirvu@yahoo.com

Cristian Drăgan University of Craiova cdragano11@gmail.com

Anca Tănasie University of Craiova ancatanasie@gmx.de

Gheorghe Axinte University Bioterra Bucharest g.axinte@yahoo.com

Mihai-lonuă Rădoi University of Craiova radoi.mi@gmail.com

Maria Enescu University of Craiova enescu.maria@yahoo.com

Recibido: octubre 2019; aceptado: mayo 2020

\begin{abstract}
The constant progress in terms of sustainable development and the achievement of Sustainable Development Goals (SDG) under 2030 Agenda are preoccupations of first concern for all the actors involved. Through this research, we conduct an investigation regarding the performance of the $28 \mathrm{EU}$ member states in terms of achievements related to sustainable development as well as the factors supporting these efforts, starting from the data provided by the SDC Index and Dashboards and Eurostat. The results highlight the importance of $R \& D$ investments as the main driver of advancement in achieving the SDGs. At the same
\end{abstract}


time, research results can provide support for policy makers and companies to contribute to more efficient allocation of available resources and maximizing the impact of relevant factors to ensure prosperity and security for people and society.

Keywords: Sustainable development, EU cohesion, 2030 Agenda, SDG Index, $R \& D$ investments.

\section{RESUMEN}

El progreso constante en términos de desarrollo sostenible y el logro de los Objetivos de Desarrollo Sostenible (ODS) bajo la Agenda 2030 son preocupaciones de primera magnitud para todos los actores involucrados. A travês de esta investigaciōn, llevamos a cabo una investigaciōn sobre el desempeño de los 28 estados miembros de la UE en términos de logros relacionados con el desarrollo sostenible, así como los factores que respaldan estos esfuerzos, a partir de los datos proporcionados por el Índice SDG y Dashboards y Eurostat. Los resultados destacan la importancia de las inversiones en I + D como principal impulsor del avance en el logro de los ODS. Al mismo tiempo, los resultados de la investigaciōn pueden brindar apoyo a los responsables políticos y a las empresas para contribuir a una asignaciōn más eficiente de los recursos disponibles y maximizar el impacto de los factores relevantes para garantizar la prosperidad y la seguridad de las personas y la sociedad.

Palabras clave: desarrollo sostenible, cohesiōn de la UE, Agenda 2030, Indice SDG, Inversiones en I + D.

Clasificación JEL JEL classification: Q01, O11, O3. 


\section{INTRODUCTION}

Starting from the fact that the recent regional development policy has as a motor the problems related to the economic, social and environmental disparities, the conflicts and tensions generated by the regional planning of the new millennium, this paper identifies in particular the correlations existing between the sustainable development of the society and the factors that generate social and economic cohesion.

Although there are many controversies about regional planning, it is now widely accepted that a number of factors can favor or block sustainable economic development and further cohesion of EU Member States. Synthetically, these factors refer to: socio-political resilience, alternative approaches to promoting sustainable urban development, policies to redirect or limit economic expansion in overcrowded or overcrowded areas, planning policies for environmental protection, including the impact of sustainable development of society (Counsell and Haughton, 2004: 264).

Regarding the concept of "sustainable regional development" we emphasize that it is used mainly in the process of elaborating regional plans in the last decade and is supported by the fact that there are different approaches to development policies in each country. Practically, we underline the presence of different geographic approaches to how sustainable development has been used to justify different types of policies in different parts of the world.

At the basis of these strategies, we can identify regional development policy programs co-financed by the EU Structural Funds and focusing mainly on regional development. On the other hand, in the European Union, cohesion policy focuses on reducing economic, social and territorial disparities. It is also interesting to highlight the fact that at the level of the European Union there are relatively similar problems in the included regions and the main financial instruments aimed at reducing the disparities are in fact the regional development programs co-financed from the structural funds of the European Union. In fact, the European Cohesion Policy mainly involves financing infrastructure and employment projects in the lagging regions of the EU Member States and this is the second most important EU budget policy. Although the main purpose is to reduce regional disparities in regional well-being, it is not yet clear whether cohesion support significantly increases economic growth (Rădulescu and Jianu, 2013: 200-206; Pîrvu et al., 2018: 1-21; Rodríguez Martín et al., 2019: 1-16; Fratesi and Wishlade, 2017: 817-821). 
Although in recent times there are visible signs of cohesion efforts, such as the Eurozone reform and European security, anti-EU points of view are evident in almost all Member States that oppose cooperation in all its forms. However, the economic crisis, which has come under the context of economic, political, social and environmental resilience, has led to an increase in cohesion, retaining the unity and cooperation of the Member States, but also the progress of the Member States (European Council on Foreign Relations, 2019: 312).

In this context there is a need to measure the level of cohesion of the EU Member States, and the EU Cohesion Monitor is currently being used as the main measuring instrument. With a complex database, this instrument mainly identifies the factors that generate cohesion. It analyzes experiences, expectations, beliefs, citizens' welfare, economic and political relationships, in a set of 42 factors generated by Eurobarometer and Eurostat. These factors are grouped into a set of ten indicators for each of the 28 Member States as well as for 12 groups of countries. We thus identify that each state has an individual cohesion profile, both economically and socially and politically (European Council on Foreign Relations, 2019:312).

In this context of sustainable development, cohesion policy at EU level has the potential to stimulate investment, promote innovation in all areas of activity, find solutions to promote an efficient Europe. In fact, this is the only strategy that generates and strengthens territorial cohesion, makes it possible to invest in green infrastructure, is a real catalyst in the transition to a green economy (Barca, 2009: 244).

This research paper aims to assess the sustainable development progress and cohesion performance in EU member states, highlighting the existing links between SDG Index and the influence factors identified, as well as identifying sustainable development models that can be adopted and replicated at EU level, so as to lead to a more efficient use of the limited resources available as well as to maximize the potential effects. Our study contributes to the development of knowledge through the analysis made at the EU country level, and also provides the knowledge and tools needed to shape a better and responsible future, addressing, in the same time, the existing gap in the current research.

\section{LITTERATURE REVIEW}

After World War II, emerging neoliberal societies developed new economic and social characteristics, particularly due to the ongoing migration phenomenon, and these imposed "new barriers to collective life and social support" (Klinenberg, 2001 : 501-531). The technological, economic, social and environmental transformations recorded in recent decades have generated a new social order, influencing the traditional ties that have underpinned the consolidation of society and which have now disappeared (Forrest and Kearns, 2001: 2125-2143).

The new patterns of social interaction have taken the place of traditional ones, but these are not fully understood, justified and not yet thoroughly analyzed. 
Understanding these new social dynamics is a profound challenge for the future of the 21 st century society, but also an opportunity to "put citizens at the center of public policies" (Polèse and Stren, 2000: 15-16). The social cohesion can thus be explained by creating and identifying large groups of individuals with well-defined social roles that develop in a social and physical setting. In this sense, large groups play a major role in defining the identity and social roles of community members (Bruhn, 2009: 157; Friedkin, 2004: 409-425; Avram et al., 2007: 56-78; Bramley and Power, 2009: 30-48; Fonseca, 2019: 231-253). In the same sense, we can identify the concept according to which social cohesion is identified by groups of individuals involved and with a different interest in the society showing group membership (Bramley and Power, 2009: 30-48).

Within the European Union, at the level of 1999, the policy of sustainable regional development and economic cohesion was divided on the nuclei of progress and opportunities on the one hand and disadvantages and obstacles on the other. Currently, it can be argued that smart, inclusive and sustainable development cooperation locally promotes a range of governance modes including the territorial dimension of cohesion. However, clear principles have yet to be laid down as to how cooperation for cohesion should be achieved (Walsh, 2012: 1-4; Böhme et al., 2011: 23-34; Pillet et al., 2014: 577-595).

From the perspective of studies that analyze cohesion policy in a PanEuropean framework, we emphasize that they provide a meta-analysis of econometric studies on the evaluation of the effects of cohesion policy. In general, there is no consensus in the literature on cohesion policy (Dall'erba and Fang, 2015). Several researchers have been concerned about assessing the effectiveness of the cohesion process, using different ways of quantification, referring to GDP growth per capita, per capita investment or regional $R \& D$ activity (Ferrara et al., 2017: 817-841; Pellegrini et al., 2013: 217-233).

From the perspective of the complexity of measuring cohesion policies, most studies find a positive conditional effect of allocating regional funds and others suggest a negative impact (Ferrara et al., 2017: 817-841;

Becker et al., 2013: 29-77). Investment projects in human capital, which generate positive effects on the cohesion phenomenon, the ability of states to attract European funding, and the increase in NUTS-2 expenditure, can also be added (Dall'erba and Fang, 2015: 1-12).

It is worth pointing out that the effects of allocating regional funds generate important conclusions on cohesion policy at EU level and allow the identification of regional best practice models in terms of financial allocation at sub-region level, developed or underdeveloped, but also from the point of view of urban and rural areas. In practice, the importance of identifying the actual and potential beneficiaries of cohesion policy in all EU Member States could help to explain the causes of the problems, the effects of allocating regional funding funds and thus to define a sustainable cohesion policy with visible results across all Member States (European Commission, 2017: 49-65; Mykhnenko and Wolff, 2019: 462-477). 
In terms of sustainable development and cohesion at EU level, it should be noted that Member States, especially those whose economic performance is inferior, do not have the effective capacity to adhere to the Maastricht criteria because their economic resources are not sufficient. This is because, in accordance with taxation and monetary discipline, unemployment may increase in these countries, it reduces wages, and this in turn generates a reduction in state budget revenues. It is also a vicious circle, and in this context, the Maastricht criteria must be seen as a result rather than as a tool for achieving sustainable economic growth and a high level of development under the conditions of political cohesion (European Commission, 2017: 49-65). However, the financial resources of the Structural Funds have been seen as a priority, thus creating the Cohesion Fund in 1993 to support economic convergence and to implement the Maastricht Treaty. This fund was intended to co-finance infrastructure and environmental projects in countries with a GDP per capita of less than $90 \%$ of the EU average: Spain, Greece, Ireland and Portugal (Holgado M. et al., 2015: 223-239; Rodríguez M. et al., 2019: 23-43).

At present, the 28 countries of the European Union are structured in a total of 276 regions, according to the Commission's statistical classification, derived from the NUTS (Nomenclature of Territorial Units). The existing discrepancies between these regions underline the need to intensify the process of economic integration through measures to promote economic cohesion between territories between Member States. In other words, after a decade of reforms and measures, it is imperative to assess regional issues, the disparities associated with the transition process, but also the regional sustainable development policy challenges identified at the level of regional, national and European decision makers (Medeiros, 2017: 1856-1875).

Thus, we can say that cohesion policy is the EU's main investment policy, the impact of cohesion policy on economies being significant. In practice, all the measures introduced aim to improve the effectiveness of the programs for 2014-2020, with particular reference to: existing conditions to stimulate structural reforms and increase administrative capacity; smart specialization strategies to exploit local potential and prioritize investments in key sectors (European Commission, 2017: 56-76).

Sustainable development in the context of cohesion across EU countries can also be addressed in terms of interactions in terms of human development objectives and policies, human well-being. Practically, determining employment levels, social protection and providing public services, such as healthcare or education, have implications and consequences for the entire region, as they can mobilize or involve resources to narrow the gaps between states. At the same time, there is a difference in the existence of differences within states, both in poor countries and rich countries. Thus, we emphasize that the political context is particularly important because the interests, ideologies and government institutions influence economic policies and, implicitly, macroeconomic outcomes (Nayyar, 2012: 7-30). 


\section{MATERIALS AND METHOdS}

In order to analyze the links between the level of performance registered by the EU Member States regarding the Sustainable Development Objectives and the factors influencing this performance, we used the official data available.

Thus, the individual performance of the analyzed countries was quantified through individual scores calculated in the SDG Index and Dashboards Report, published by the UN Sustainable Development Solutions Network in cooperation with the Bertelsmann Stiftung (Sachs et al., 2018: 35-64).

The country-specific SDG index published in the SDG Index and Dashboards takes into account all available data for each of the 17 SDGs, aggregating them into a composite index to provide countries with a rapid assessment of their performance against the other neighboring countries or similaires. Thus, the SDG index can help draw attention to SDGs and their role as a tool for guiding national policies and long-term strategies for sustainable development. Its aim is not to compare countries with a very different development status, but to allow countries to assess individually, using a holistic measure that includes all SDGs and treats each objective equally.

Regarding the factors that influence the achievement of SDG, following the analysis of the results published in the available research papers (Uzzell et al., 2002: 26-53; Hirschi, 2010: 16; Tausch, 2003: 1-41; Manta and Badircea 2014: 23-34; Eurostat, 2018, p.56), we selected the following 6 factors that have proved to have a significant influence on the sustainability: Gross Domestic Product (RDP), Share of the number of people at risk of poverty or social exclusion in total population (PRP), Gross Domestic Product (DGDP) total debt, Adult participation in the learning process (ALP), Share of research expenditure -European Gross Domestic Product (GERD) development, European Union Structural and Investment Fund absorption (EUPR). Data on use variables were collected from the Eurostat database and the synthetic values are presented in Table 1:

The data collected to analyze the links between the performance levels registered by the EU Member States in the field of sustainable development

TABle 1. Descriptive statistics

\begin{tabular}{l|c|c|r|r|r}
\multicolumn{1}{c|}{ Variable } & N & Minimum & \multicolumn{1}{c|}{ Maximum } & \multicolumn{1}{c}{ Mean } & \multicolumn{1}{c}{ Std. Deviation } \\
\hline SDG Index & 28 & 70.4 & 85 & 76.9786 & 4.03718 \\
\hline RGDP & 28 & 6300 & 80300 & 26610.7143 & 16709.72968 \\
\hline PRP & 28 & 12.2 & 38.9 & 22.8321 & 6.53504 \\
\hline DGDP & 28 & 9.2 & 176.2 & 68.0393 & 37.21499 \\
\hline ALP & 28 & 0.9 & 29.2 & 11.4857 & 7.54604 \\
\hline GERD & 28 & 0.5 & 23.17 & 1.5693 & 0.88178 \\
\hline EUPR & 28 & 7.26 & & 14.1475 & 4.28825 \\
\hline Valid N (listwise) & 28 & & &
\end{tabular}

Source: Own construction using SPS. 
and the factors influencing this performance have been processed and analyzed using the IBM SPSS Statistics (Popa, 2008: 78-96) software program and Microsoft Excel (Zaharia and Oprea, 2011: 23-29).

Thus, in order to identify the functional links existing between the SDG Index dependent variable and the six predictors, the diagonal matrix $\mathrm{B}$ and the vector VI of the predictors (independent variables) were composed:

$B=\left(\begin{array}{cccc}b_{1} & 0 & \ldots & 0 \\ 0 & b_{2} & \ldots & 0 \\ \ldots & \ldots & \ldots & \ldots \\ 0 & 0 & \ldots & b_{k}\end{array}\right) \quad V I=(R G D P$ PRP DGDP ALP GERD EUPR $)$

Taking into account what has been said so far, using the modified version of the Ohlson model (1995) (Ohlson, 1995: 661-687), Model_1 was created using the following equation:

Model_1: $\quad$ SDG_Index $=a+B \times V I^{\top}+\varepsilon, \quad a \in R, \quad B \in M_{6 \times 6}, \quad \varepsilon \sim N\left(0, \sigma_{\varepsilon}^{2}\right)$

\section{RESULTS AND DISCUSSION}

The data analysis presented in Table 2 shows that Model_1 estimates a significantly high influence of predictor values on the SDG Index. A first piece of information is provided by the value of the multiple correlation coefficient $(R=0.962)$, which shows that there is a high correlation between the SDG Index result and the predictors $\left(\mathrm{VI}_{\mathrm{k}}\right)$. Moreover, the value of the coefficient of

TAble 2. Model summary and ANOVA for Model_1

\begin{tabular}{|c|c|c|c|c|c|}
\hline$R$ & R_Square & Adjusted R_Square & Std. Error of the Estimate & \multicolumn{2}{|c|}{ Durbin-Watson } \\
\hline $.962^{\mathrm{a}}$ & 0.926 & 0.905 & 1.24286 & & 1.533 \\
\hline \multicolumn{6}{|l|}{ ANOVA } \\
\hline & Sum of Squares & df & Mean Square & $\mathrm{F}$ & Sig. \\
\hline Regression & 407.628 & 6 & 67.938 & 43.981 & $.000^{\mathrm{b}}$ \\
\hline Residual & 32.439 & 21 & 1.545 & & \\
\hline Total & 440.067 & 27 & & & \\
\hline
\end{tabular}

a. Dependent Variable: SDG Index. b. Predictors: (Constant), EUPR, GERD, DGDP, RGDP, PRP, ALP. Source: Own construction using SPSS. 
determination R_Square $\left(\mathrm{R}^{2}\right)$ shows that the variation of the SDG Index variable is determined in $92.6 \%$ by the combined variability of the predictors.

At the same time, the result of applying the ANOVA methodology indicates that Model_1, taken as a whole, is statistically significant, which means that the influence of regressors is significantly greater than the influence of residues. This conclusion is based on the fact that the calculated value of the statistics $F$ $(43,981)$ is much higher than the critical value $F_{0.05 ; 6 ; 21}=2.57$ and the value of Sig. $=0.000<\alpha=0.05$.

The values presented in Table 2, as well as the previous findings, refer only to Model_1, viewed as a whole. To validate or invalidate the model structure, it is necessary to analyze the statistical significance of predictor values $\left(\mathrm{VI}_{\mathrm{k}}\right)$ and coefficients $\left(b_{k}\right)$. Their characteristics are shown in Table 3.

Table 3. Characteristics of Model_ 1 coefficients

\begin{tabular}{|c|c|c|c|c|c|c|c|}
\hline \multirow{2}{*}{ Variable } & \multicolumn{2}{|c|}{$\begin{array}{l}\text { Unstandardized } \\
\text { Coefficients }\end{array}$} & \multirow{2}{*}{$\frac{\begin{array}{c}\text { Standardized } \\
\text { Coefficients }\end{array}}{\beta}$} & \multirow{2}{*}{$\mathrm{t}$} & \multirow[t]{2}{*}{ Sig. } & \multicolumn{2}{|c|}{$95 \%$ Confidence Interval for $B$} \\
\hline & $B$ & Std. Error & & & & Lower Bound & Upper Bound \\
\hline a (const.) & 76.923 & 1.648 & & 46.666 & 0.000 & 73.495 & 80.351 \\
\hline RGDP & $-3.138 \mathrm{E}-05$ & 0.000 & -0.130 & -1.545 & 0.137 & 0.000 & 0.000 \\
\hline PRP & -0.082 & 0.050 & -0.133 & -1.635 & 0.117 & -0.186 & 0.022 \\
\hline DGDP & -0.016 & 0.007 & -0.149 & -2.326 & 0.030 & -0.031 & -0.002 \\
\hline ALP & 0.208 & 0.062 & 0.389 & 3.382 & 0.003 & 0.080 & 0.336 \\
\hline GERD & 2.757 & 0.416 & 0.602 & 6.633 & 0.000 & 1.892 & 3.621 \\
\hline EUPR & -0.202 & 0.067 & -0.214 & -3.008 & 0.007 & -0.341 & -0.062 \\
\hline
\end{tabular}

a. Dependent Variable: SDG Index.

Source: Own construction using SPSS.

As we can observe, out of the six Model_1 coefficients only 4 of them record values significantly different from zero. Regarding the coefficient of RGDP variable Sig. $=0.137>\alpha=0.05$, and for the variable PRP coefficient Sig. $=0.117>\alpha=0.05$, it follows that the null hypothesis is accepted for them and therefore these coefficients are not statistically significant and should be removed from the model.

Thus, we will create a new model, Model_2, which differs from the previous model Model_1 only in terms of the size of the diagonal matrix B and the structure of the vector VI

$$
\begin{array}{r}
\text { Model_2: SDG_Index }=a+B \times V I^{\top}+\varepsilon, a \in R, \varepsilon \sim N\left(0, \sigma_{\varepsilon}^{2}\right) \\
\text { where } B \in M_{4 \times 4}, V I=(D G D P \text { ALP GERD EUPR })
\end{array}
$$


The main parameters, as well as the results of applying the ANOVA methodology for Model_2 as a whole, are presented in Table 4.

Table 4. Model summary and ANOVA for Model_2

Model Summary

\begin{tabular}{|c|c|c|c|c|c|}
\hline$R$ & R_Square & Adjusted R_Square & Std. Error of the Estimate & \multicolumn{2}{|c|}{ Durbin-Watson } \\
\hline $.953^{a}$ & 0.908 & 0.892 & 1.32813 & \multicolumn{2}{|c|}{1.730} \\
\hline \multicolumn{6}{|l|}{ ANOVA } \\
\hline & Sum of Squares & $d f$ & Mean Square & $\mathrm{F}$ & Sig. \\
\hline Regression & 399.497 & 4 & 99.874 & 56.620 & $.000^{\mathrm{b}}$ \\
\hline Residual & 40.570 & 23 & 1.764 & & \\
\hline Total & 440.067 & 27 & & & \\
\hline
\end{tabular}

a. Dependent Variable: SDG Index.

b. Predictors: (Constant), EUPR, GERD, DGDP, ALP.

Source: Own construction using SPSS.

A first conclusion is that there is a high intensity correlation in Model_2 between the result variable SDG Index and the predictors $\left(\mathrm{VI}_{\mathrm{k}}\right)$, the value of the multiple correlation coefficient (R) being 0.953. Also, the value of the R_ Square determinant indicates that the variation of the SDG Index variable is $90.8 \%$ determined by the combined variability of the predictors analyzed.

As for the statistical significance of Model_2 for a 95\% confidence level, since both the calculated F-statistic value $=60.809$ is significantly higher than the critical value $F_{0.05 ; 4 ; 23}=2.80$ and the value of Sig. $=0.000<\alpha=0.05$, it follows that the null hypothesis is rejected and the alternative hypothesis is accepted and therefore Model_2 is valid and statistically significant for the significance level chosen.

On the other hand, as can be seen from the data presented in Table 5, all four predictor $b_{k}$ coefficients are statistically significant (significantly different from zero). This conclusion results from the fact that all values of the statistics $\mathrm{t}$ (Student test) belong to the critical region, $\mathrm{t}>\mathrm{t}_{0.025 ; 27}=2.052$, and from that Sig. $=0.000<\alpha=0.05$.

In conclusion, Model_2 is also structurally valid (statistically significant), the coefficients of the predictors, for the chosen significance level, taking values within the confidence interval (Table 5) corresponding to each one.

In order to determine the values of the coefficients of the $b_{k}$ predictors, the presence of influential cases and extreme cases, as well as multi-collinearity and independence (i.e. lack of autocorrelation) of the residual hypothesis $(\varepsilon)$, were verified.

Extreme cases can affect the stability of the regression equation of Model_2. Existence of extreme cases is signaled by Std minimum values. Residual and 
TABle 5. Characteristics of Model_2 COefficients

\begin{tabular}{|c|c|c|c|c|c|c|c|}
\hline \multirow{2}{*}{ Variable } & \multicolumn{2}{|c|}{$\begin{array}{l}\text { Unstandardized } \\
\text { Coefficients }\end{array}$} & \multirow{2}{*}{$\begin{array}{c}\begin{array}{c}\text { Standardized } \\
\text { Coefficients }\end{array} \\
\beta\end{array}$} & \multirow{2}{*}{$\mathrm{t}$} & \multirow[t]{2}{*}{ Sig. } & \multicolumn{2}{|c|}{$\begin{array}{l}\text { 95\% Confidence Interval } \\
\text { for } B\end{array}$} \\
\hline & B & Std. Error & & & & $\begin{array}{l}\text { Lower } \\
\text { Bound }\end{array}$ & $\begin{array}{l}\text { Upper } \\
\text { Bound }\end{array}$ \\
\hline a (const.) & 74.174 & 1.077 & & 68.876 & 0.000 & 71.946 & 76.402 \\
\hline DGDP & -0.019 & 0.007 & -0.175 & -2.601 & 0.016 & -0.034 & -0.004 \\
\hline ALP & 0.183 & 0.052 & 0.343 & 3.518 & 0.002 & 0.076 & 0.291 \\
\hline GERD & 2.976 & 0.423 & 0.650 & 7.036 & 0.000 & 2.101 & 3.851 \\
\hline EUPR & -0.189 & 0.063 & -0.201 & -2.987 & 0.007 & -0.320 & -0.058 \\
\hline
\end{tabular}

a. Dependent Variable: SDG Index.

Source: Own construction using SPSS.

Stud. Residual (Table 6), which should also be in the range $[-2,0,2,0]$. Table 6 shows that there are negative values outside this range. The minimum values $(-2,017$ and $-2,256)$ correspond to a single country (Austria), respectively there is one extreme case that does not belong to the domain $[-2,0,2,0]$, but is included in the range $[-3,0,3.0]$. Given the fact that the percentage of extreme cases in the total cases analyzed is $3.57 \%<5.0 \%$, the hypothesis is assumed that the regression equation Model_2 can be considered stable.

To check for cases that can throw regression coefficient values $b_{k}$ (Labar, 2008: 56-87), we analyze the Cook's distance values. Since all of the 28 values of Cook's distance are much smaller than 1, it is obvious that there are no influential cases within the sample and therefore the values of the $b_{k}$ coefficients are not influenced by them.

Verification of residue independence $(\varepsilon)$ was performed by applying the Durbin-Watson test (Table 4). Given that the analyzed sample contains $N=28$ elements and the number of predictors is 4 , the Durbin-Watson distribution table for $\alpha=0.05$ shows the value $d_{U}=1.65025$ (Savin and White, 1977: 1989-1996). Since $D W=1.730 \in\left(d_{u}=1.65025,4-d_{u}=2.34975\right)$, we accept the null hypothesis, i.e. the residues $(\varepsilon)$ are not auto correlated.

TABle 6. Residuals Statistics

\begin{tabular}{l|r|r|r|r|r} 
& \multicolumn{1}{|c|}{ Minimum } & Maximum & \multicolumn{1}{c|}{ Mean } & \multicolumn{1}{c}{ Std. Deviation } & N \\
\hline Residual & -2.67890 & 2.46030 & 0.00000 & 1.22581 & 28 \\
\hline Std. Residual & -2.017 & 1.852 & 0.000 & 0.923 & 28 \\
\hline Stud. Residual & -2.256 & 1.972 & -0.007 & 1.010 & 28 \\
\hline Cook's Distance & 0.000 & 0.255 & 0.040 & 0.059 & 28
\end{tabular}

Source: Own construction using SPSS. 
For verification of collinearity, specific data were analyzed (Table 7). The condition of avoiding collinearity is that the tolerance values corresponding to the four predictors must be greater than (1 - R² adjusted). For Model_2, the adjusted $\mathrm{R}^{2}$ value is 0.892 (Table 4). Taking this into account, the condition of avoiding collinearity is fulfilled because all Tolerance values (Table 7) are greater than 0.108 . The same conclusion is disregarded if we take into account that the VIF values (VIF $=1$ / Tolerance) recorded by the four predictors are less than 9.259.

Table 7. Standardized coefficients, Correlations, and collinearity statistics for Model_2

\begin{tabular}{|c|c|c|c|c|c|c|}
\hline \multirow{2}{*}{ Variables } & \multirow{2}{*}{$\begin{array}{c}\begin{array}{c}\text { Standardized } \\
\text { Coefficients }\end{array} \\
\text { Beta }\end{array}$} & \multicolumn{3}{|c|}{ Correlations } & \multicolumn{2}{|c|}{ Collinearity Statistics } \\
\hline & & Zero-order & Partial & Part & Tolerance & VIF \\
\hline DGDP & -0.175 & -0.242 & -0.477 & -0.165 & 0.884 & 1.131 \\
\hline ALP & 0.343 & 0.780 & 0.592 & 0.223 & 0.423 & 2.365 \\
\hline GERD & 0.650 & 0.881 & 0.826 & 0.445 & 0.470 & 2.129 \\
\hline EUPR & -0.201 & -0.127 & -0.529 & -0.189 & 0.885 & 1.130 \\
\hline
\end{tabular}

Source: Own construction using SPSS.

The overall conclusion that emerges from the Model_2 analyses is that it qualifies for use in predictor analysis (Total State Debt on Gross Domestic Product, Adult Participation in Learning Process, Ratio of R\&D expenditures in Gross Domestic Product and Degree absorption of European structural and investment funds) on the dependent variable SDG Index. Partial and Part values of predictors are the values of the partial $\left(r_{\mathrm{p}}\right)$ and semi-partial $\left(r_{\mathrm{sp}}\right)$ correlation coefficients between the predictors and the dependent variable.

In Table 7, zero-order correlations are represented by the Pearson correlation coefficients for each of the four predictors (independent variables) and the SDG Index (dependent variable). The Pearson correlation coefficients thus determined highlight the direct and average linkages between the predicted predictors and the SDG Index. Thus, the most important variable is the share of $R \& D$ expenditures in GDP (GERD), and the smallest significance is the share of GDP total government debt (DGDP). Also, information on the influence of predictors on the SDG Index is also highlighted by the standardized coefficient values confirming the above.

The most conclusive information on the influence of each predictor on the SDG Index is obtained taking into account the $r_{\text {sp }}$ values that allow the determination of the corresponding determinants of each predictor $\left(r_{\mathrm{sp}}{ }^{2}\right)$. They point out that the share of $R \& D$ expenditures in GDP (GERD) has the 
greatest influence on SDG Index and $19.85 \%$ of SDG Index variation due to $\mathrm{R} \& \mathrm{D}$ investment.

For the other predictors, the SDG Index variation can be explained by a much smaller proportion: $4.96 \%$ by the number of adults in the learning process, $3.58 \%$ by the degree of absorption of European structural and investment funds and $2.71 \%$ by the share of total government debt to GDP. It should be noted that overall, due to the synergistic effect, the four predictors influence the SDG Index by $90.8 \%$ (Table 4).

To highlight the fact that the share of R\&D expenditure in GDP (GERD) has the greatest influence on SDG Index and $19.85 \%$ of SDG Index variation respectively. From the perspective of the other factors of influence analyzed, we find a much lower proportion of: $4.96 \%$ of the share of the number of adults in the learning process (ALP), 3.58\% of the absorption degree of the structural funds and of the European investments EUPR) and $2.71 \%$ of the total government debt-to-GDP ratio (DGDP). Indeed, research and development, as demonstrated by practice, is an essential component of innovation and an undisputed key factor in developing new competitive advantages for countries on the global and regional markets (Hametner et al., 2010: 1-49; Kostrzewa and Piasecki, 2009: 181-196).

Therefore, the innovation and the capacity of the innovation countries are the key to the progress of the future society. In other words, the financial availability of countries to invest in technology becomes a strategic priority, because innovation capacity is the only one that can generate new products, new processes and sustainable services that meet the new global challenges and needs.

We can say that investing in research and development is one of the ingredients that provides access to knowledge, to new technology, to progress and competitive advantages. As a predictor of sustainable development performance and meeting the SDGs, we can also point out that innovation and $R \& D$ spending generate a great deal of knowledge, and financing this segment of the economy is, in this context, an undeniable strategic priority but also a stimulating factor for the cohesion of EU Member States. As a confirmation of the results obtained from this study, as well as of the importance given to investments in R\&D and the creation of new knowledge, research carried out outside the European Union, but which have produced similar results, can also be mentioned. Thus, in a similar research, Al-Roubaie highlights the importance of building knowledge capacity for sustainable development in the Arab World and demonstrates that developing countries are in a better position to gain access to global knowledge through building knowledge capacity (Al-Roubaie, 2013: 7-20). Similar results have also been obtained by Zbuchea et al. (2019: 359) or Saczyna (2015: 133-141) which emphasizes that knowledge assets and technological enhancements have essential strategic resources for any organization to achieve competitive advantage and sustainability.

On the other hand, innovation means investment and government involvement through programs and specific projects, through adequate funding 
targets long-term sustainable development becomes a priority. However, it appears to be an extremely important issue, but also a subject of interest for the future, the inability of companies, irrespective of their size, to invest in innovation, to develop new, sustainable products and services. This is because, although identified as a competitive advantage, innovation sometimes appears to be almost impossible, especially for small companies where financial resources are limited and where funding sources seem to be non-existent for this objective. In this segment, where the risks are high, where the capacity for resilience to change and progress is small, there is a need for government funding.

By increasing the R\&D budget allocation for EU member countries, through the European funding of regional innovation projects, progress is accelerated indubitable, knowledge transfer, value is created through the renewal of science and technology, thus offering economic and social benefits, but also strengthening the cohesion process at regional level. Therefore, innovation as a result of higher spending on research development is the most important factor that creates economic, political and social cohesion by guaranteeing growth in employment, sustainable growth, social welfare and quality of life.

Indeed, the EU's long-term budget 2021-2027 proposes modernizing cohesion policy and most of the European Regional Development Fund and Cohesion Fund's investment will focus on innovation, support for small businesses, digital technologies and industrial upgrading. Also, a cohesion policy is targeted for all regions, including richer countries. In addition, the new criteria aim to better reflect on the ground - youth unemployment, low levels of education, climate change and the reception and integration of migrants (European Commission, 2018: 25-36).

\section{Conclusions}

Sustainable global development is currently an unquestionable strategy. With a major impact on progress and quality of life, sustainable development is a subject of ongoing debate, monitoring progress and identifying factors that influence progress is one of the major concerns of decision-makers and not only.

Starting from these considerations but also from the results obtained by the European Union member states regarding the Sustainable Development Objectives and also from the factors influencing the performance, our research analyzed the links between them, respectively the level of registered performance by the member countries and the framework elements that influence this performance in the context of the conceptual framework of European cohesion. Thus, with a significant influence on the degree of sustainable development, we identified: Gross Domestic Product (RGDP), Share of the number of people at risk of poverty or social exclusion in the total population (PRP), Total state debt related to Domestic Product Gross Value 
Added (DGDP), Adult Participation in Learning Process (ALP), Ratio of $R \& D$ expenditures in Gross Domestic Product (GERD), European Union Structural and Investment Fund absorption rate (EUPR).

Through the identified correlations, the findings of our research are extremely relevant from the perspectives of the sustainable development directions of the future society in the context of political, economic, social and territorial cohesion, and also highlights the priority direction governments and all stakeholders directly or indirectly in implementing sustainable, they can go through it.

We can conclude that sustainable regional development and cohesion policy at European level have unquestionable results and that the European future after 2020 must be seen in a new framework, focusing on the top priorities in terms of investment policy. We can note that at the level of the period 2021-2027, investments at the level of the EU countries will focus especially on research, innovation, and the ERDF and Cohesion Fund resources will be allocated to these priorities (European Commission, 2018a: 56-78).

New approaches to sustainable development in the context of European cohesion need to be based in particular on: innovation, digitization, economic transformation and support for small and medium-sized enterprises, investments in energy transition, investments in renewable energies, promotion of social rights and support for the quality of employment, education, skills, social inclusion and equal access to healthcare, supporting local development strategies and sustainable urban development.

Also, we conclude that cohesion policy will continue to invest in all regions, on the same categories of countries (less developed, transition, more developed), the method of allocating funds still based on GDP per capita. As our research highlights, regional sustainable development is obvious and can be sustained in the future through a new dimension, through the creation of communication networks and by strengthening national and local capacities to have initiatives, support initiatives, innovate, to manage and promote innovation, to manage and promote progress.

The results obtained from this empirical research should also be viewed in light of the potential limitations it implies but which can open new directions for future research. A limitation of this research is related to the selected sample and the availability of information. The results of this study may be limited by the way data is reported, as well as by the models used to obtain aggregate values. Often, the available information is not easy to quantify, and each model data provider owns, so the SDG Index value and related scores may vary depending on each rating company.

At the same time, the results of this research can serve as a starting point for future research on sustainable development models, the extension of the set of variables used, and the attempt to identify a generalized model in order to be able to follow the effectiveness of public policies and strategies adopted in each country analyzed. This future study could improve knowledge in terms of supporting sustainable development and delivering the most appropriate and 
effective public policies to achieve the Sustainable Development Objectives as set out in the 2030 Agenda.

\section{REFERENCES}

Al-Roubaie, A. (2013). Building Knowledge Capacity for Sustainable Development in The Arab World. IJIKMMENA, 2(1), 7-20.

Avram, C., Radu, R., Pirvu, G., and Gruescu, R., (2007). Romania and The Requirements of European Integration (pp. 200-218), Craiova: Alma.

Barca, F. (2009). An Agenda for A Reformed Cohesion Policy: A Place-Based Approach to Meeting European Union Challenges and Expectations. Independent report prepared at the request of the European Commissioner for Regional Policy, Retrieved 10 April 2019.

http://ec.europa.eu/regional_policy/policy/future/barca_en.htm.

Becker, S.O., Egger, P.H. and von Ehrlich, M. (2013). Absorptive Capacity and the Growth and Investment Effects of Regional Transfers: A Regression Discontinuity Design with Heterogeneous Treatment Effects. American Economic Journal: Economic Policy, 5(4), 29-77.

Bramley, G. and Power, S. (2009). Urban Form and Social Sustainability: The Role of Density and Housing Type. Environment and Planning B: Planning and Design, 36(1), 30-48.

Böhme K., Doucet P., Komornicki T., Zaucha J., and Świątek D. (2011). How to Strengthen the Territorial Dimension of 'Europe 2020' and EU Cohesion Policy, Warsaw.

Bruhn, J. (2009). The Group Effect: Social Cohesion and Health Outcomes. Springer-Verlag US, https://doi.org/10.1007/978-1-4419-0364-8.

Counsell, D. and Haughton, G. (2004). Regions, Spatial Strategies and Sustainable Development. 1 st Edition, Routledge, London, https://doi.org/10.4324/9780203561249.

Dall'erba, S. and Fang, F. (2015). Meta-Analysis of the Impact of European Union Structural Funds on Regional Growth. Regional Studies, 51, 1-12.

European Commission, (2008). Turning Territorial Diversity into Strenght, Green Paper on Territorial Cohesion. Retrieved 10 April 2019 from: http://eur-lex. europa.eu/LexUriServ/LexUriServ.do? uri=COM:2008:061 6:FIN:EN.

European Commission, (2017). My region, My Europe, Our future: The 7th report on economic, social and territorial cohesion. Report from the Commission to the European Parliament, the Council, the European Economic and Social Committee and the Committee of the Regions. Retrieved 20 April 2019 from: https://ec.europa.eu/regional_policy/sources/docoffic/official/ reports/cohesion $7 / 7 \mathrm{cr}$.pdf

European Commission, (2018). Regional Development and Cohesion Policy 2021-2027. Retrieved 15 April 2019 from:

https://ec.europa.eu/regional_policy/en/newsroom/news/2018/06/06-082018-regional-development-and-cohesion-policy-2021-2027. 
European Commission (2018a). Regional Development and Cohesion Policy beyond 2020: The New Framework at a glance. Retrieved 27 April 2019 from: https://ec.europa.eu/regional_policy/en/2021_2027/.

European Council on Foreign Relations, (2019). EU Cohesion Monitor. Retrieved 21 April 2019 from:

https://www.ecfr.eu/page/ECFR281_EU_COHESION_MONITOR_2019.pdf

Eurostat, (2018). Sustainable development in the European Union - Monitoring report on progress towards the SDGs in an EU context. Retrieved 21 April 2019 from: https://ec.europa.eu/eurostat/web/products-statistical- books /-/ KS-01-18-656 eucohesionmonitor.

Ferrara, A., McCann, P., Pellegrini, G., Stelder, D. and Terribile, F. (2017). Assessing the Impacts of Cohesion Policy on EU Regions: A Non-Parametric Analysis on Interventions Promoting Research and Innovation and Transport Accessibility. Papers in Regional Science, 96(4), 817-841.

Fonseca, X., Lukosch, S. and Brazșier. F. (2019). Social Cohesion Revisited: A New Definition and How to Characterize it. Innovation: The European Journal of Social Science Research, 32(2), 231-253.

Forrest, R. and Kearns, A. (2001). Social Cohesion, Social Capital, and the Neighbourhood. Urban Studies, 38(12), 2125-2143.

Fratesi, U. and Wishlade, F.G. (2017). The Impact of European Cohesion Policy in Different Contexts. Regional Studies, 51(6), 817-821.

Friedkin, N.E. (2004). Social Cohesion. Annual Review of Sociology, 30, 409-425.

Hametner, M., Martinuzzi, A., Sedlacko, M., Gjoksi, N. and Endl, A. (2010). Research \& Development for Sustainable Development: How European R\&D Activities and Programmes Contribute to SD. ESDN Quarterly Report, 1-49.

Hirschi, C. (2010). Strengthening Regional Cohesion: Collaborative Networks and Sustainable Development in Swiss Rural Areas. Ecology and Society, 15(4), 16.

Holgado Molina, M.M., Salinas Fernández, J.A. and Rodriguez Martín, J.A., (2015). A Synthetic Indicator to Measure the Economic and Social Cohesion of the Regions of Spain and Portugal. Revista de Economia Mundial, 223239.

Klinenberg, E. (2001). Dying Alone: The Social Production of Urban Isolation. Ethnography, 2(4), 501-531.

Kostrzewa, K. and Piasecki, R. (2009). Approaches to Sustainable Development in Poland, L'Europe en Formation, 352(2), $181-196$.

Labar, A.V. (2008): SPSS for Educational Sciences (pp. 257-286), lasi: Polirom.

Manta, A.G. and Badircea R. (2014): Measuring the Efficiency in the Romanian Banking System Through the Method of the Data Envelopment Analysis. Annals of University of Craiova - Economic Sciences Series, 1(42), 23-34.

Medeiros, E. (2017): From Smart Growth to European Spatial Planning: A New Paradigm for EU Cohesion Policy Post-2020. European Planning Studies, 25(10), 1856-1875. 
Mykhnenko, V. and Wolff, M. (2019): State Rescaling and Economic Convergence. Regional Studies, 53(4), 462-477.

Nayyar, D. (2012): Macroeconomics and Human Development. Journal of Human Development and Capabilities, 13(1), 7-30.

Ohlson, J.A. (1995): Earnings, Book Value, and Dividends in Equity Valuation. Contemporary Accounting Research, 11 (2), 661 - 687.

Painter, J. (2006): Prosaic geographies of stateness. Political Geography, 25(7), $752-774$

Pellegrini, G., Terribile, F., Tarola, O., Muccigrosso, T. and Busillo, F. (2013): Measuring the Effects of European Regional Policy on Economic Growth: Regression Discontinuity Approach, Papers in Regional Science, 92(1), 217-233.

Pillet, F., Cañizares, M.C., Ruiz, A.R., Martinez, H., Plaza, J. and Santos, J.F. (2014): Applying the European Spatial Development Perspective in Lowdensity Regions: A Methodology Based on Mobility and Labour Market Structure, Urban Studies, 51(3), 577-595.

Pîrvu R., Bădîrcea R., Manta A. and Lupăncescu M., (2018): The Effects of The Cohesion Policy on the Sustainable Development of the Development Regions in Romania. Sustainability, 10(7), 1-21.

Polèse, M. and Stren, R.E. (2000): The Social Sustainability of Cities: Diversity and the Management of Change (pp. 15-16.): London: Buffalo.

Popa, M. (2008): Statistics for psychology. Theory and applications SPSS II edition revised and added (pp. 225-240). București: Polirom.

Rădulescu, M. and Jianu, E. (2013) The Impact of the Foreign Direct Investments on the Economic Growth in Central and Eastern European Countries, Metalurgia International, 8, 200-206.

Rodríguez Martín, J.A., Martín Martín, J.M., Salinas Fernāndez, J.A., Zermeño Mejīa, K.A. and, Añaños Bedriñana, K.G. (2019): A Spatial Analysis of the Achievements, in Terms of Regional Development, Accomplished by the Initial EU-Member Cohesion Fund Beneficiaries Using a Synthetic Indicator, Sustainability, 11, 1-16.

Sachs, J., Schmidt-Traub, G., Kroll, C., Lafortune, G. and Fuller, G. (2018): SDG Index and Dashboards Report (pp.476), New York: Bertelsmann Stiftung and Sustainable Development Solutions Network (SDSN).

Saczyna, M. (2015): Achieving Environmental Sustainability through Knowledge Management: a Survey Conducted among Corporates in the Czech Republic. Journal of Intercultural Management, 7(3), 133-141.

Savin, N.E. and White, K.J. (1977): The Durbin-Watson Test for Serial Correlation with Extreme Sample Sizes or Many Regressors. Econometrica, 45, 1989-1996.

Tausch, A. (2003): Social Cohesion, Sustainable Development and Turkey's Accession to the European Union: Implications from a Global Model. Turkish Journal of International Relations, 2(1), 1-41. 
Uzzell, D.L., Pol, E. and Badenes, D. (2002): Place Identification, Social Cohesion and Environmental Sustainability. Environment and Behavior, 34(1), 26-53.

Walsh, C. (2012): Territorial Agenda of the European Union 2020: Towards an Inclusive, Smart and Sustainable Europe of Diverse Regions. Planning Theory \& Practice, 13, 1-4.

Zaharia, M. and Oprea, C. (2011): Elements of automatic analysis and model for using Excel (pp. 145-162), Bucharest: University Publishing House.

Zbuchea, A., Pînzaru, F., Busu, M., Stan, S.O. and Bârgăoanu, A. (2019) Sustainable Knowledge Management and Its Impact on the Performances of Biotechnology Organizations, Sustainability, 11, 359. 
